pany which took title to his property and then mortgaged it to $D$ and agreed to pay a large bonus in addition to interest to obtain a loan. The rate of $6 \%$ was the inaxinum which could be exacted from an individual borrower, but a corporation could not plead usury under the statute. The borrower's attempt to set aside a mortgage foreclosure in equity was denied. Since the borrower had adopted the corporate device to obtain the money and had not been imposed upon, the equities of the case did not call for a limitation of the corporate privilege which he had utilized. But the line between what is an evasion of the law and what is a permissive use of the separate corporate entity may sometimes be a close one.

Henry W.Ballantine.*

\title{
MORTGAGES AND TRUST DEEDS: ENFORCEMENT OF A SECURED DEBT IN CALIFORNIA
}

In order to appraise that phase of the law in California which governs the procedure for the enforcement of a debt secured by a mortgage or deed of trust, it is essential to have in mind the origin and development of the "one action" provision found in section 726 of the Code of Civil Procedure. Before considering the judicial interpretation of the rule, it is helpful to make a brief survey of its statutory history.

The "one action rule" first appeared in California by an amendment made in 1860 to section 246 of the Civil Practice Act. It provided that "There shall be but one action for the recovery of any debt, or the enforcement of any right secured by a mortgage. ..." Since 1872, section 246 of the Civil Practice Act has been known as section 726 of the Code of Civil Procedure. However, the first sentence of section 726 which embodies the "one action" rule has undergone no material change since its original enactment over eighty years ago. ${ }^{1}$ It will be found that the amendment in 1860 to the Practice Act was an attempt to restate and incorporate section $905^{2}$ of

\#Professor of Law, University of California.

IIn 1933 the first sentence of section 726 was amended to read, "There can be but one form of action for the recovery of any debt. ..." This change was apparently of no consequence. See Note (1937) 25 CALIF. L. Rev. 469, 470.

While there have been various changes in and amendments to the remaining provisions of section 726 , the basic requirements of a single action involving (1) a judicial sale of the security and (2) a deficiency judgment for the balance due on the debt has always existed.

2 Section 905 of the proposed New York Code of Civil Procedure of 1850 reads as follows: "When a debt is secured by mortgage of real or personal property, or a hen or encumbrance thereon, separate actions respecting the debt and the security cannot be allowed, but the creditor must include in one action all his claims upon both." (Italics added) p. 385 . 
the proposed New York Code of Civil Procedure of 1850, which section was omitted when sections 903 and 906 of the proposed New York Code of Civil Procedure were adopted by California in $1851 .^{3}$ It is of interest to note that the proposed New York Code of Civil Procedure of 1850 never became law in that state, and to this day there is no such mystery as the "one action" rule in New York or any other code state which derived its laws from the New York Code of Procedure of 1848 in its original or amended form. ${ }^{4}$ In several western states the one action rule exists today, ${ }^{5}$ but only because the law of California rather than that of New York was used as the pattern.

The judicial interpretation of this anomalous statutory provision has been anything but judicious. Much of the confusion may be ascribed to the failure of the court to distinguish between the purpose of the statutory "one action" rule and its effect. "The express purpose of section 905 of the proposed New York Code of Civil Procedure of 1850, from which section 726 was derived, was stated to be "to prevent a multiplicity of actions." 7 At common law the creditor had three actions which he could bring independently or concurrently where a debt was secured by a mortgage. ${ }^{8}$ The sole intention of

3 These sections of the proposed New York Code of Civil Procedure of 1850 werc adopted as sections 246 and 247 of the laws of California. Laws of California (1853) Chapter CXXIII, Tit. VIII, c. I, pp. 519, 565.

4. The first report of the New York Code of Procedure of 1848 was submitted by Loomis, Graham, and Field on February 29, 1848, and was adopted by the New York Legislature in that year and later amended. This code must be distinguislied from the New York Code of Civil Procedure of 1850 which was submitted by the same draftsmen on December 31, 1849, and was rejected in toto by the New York legislature.

The California legislature, however, was more receptive and adopted many of the provisions of the New York Code of Civil Procedure of 1850.

5 Statutes similar to section 726 are found in the following states: Idaho, Inarro Code Ann. (1932) \$9-101; Montana, Mont. Rev. Codes ANN. (Anderson and McFarland, 1933) \$9467; Nevada, Nev. Comp. LAws (Hillyer, 1929) §9048; Utah, UtAH REv. STAT. (1933) \$104-55-1.

6 In several cases, however, the court las distinguished between the purpose and effect of section 726, and has interpreted the section in accordance with its actual intent, namely, to prevent the debtor from being subject to more than one suit (and not as a requirement that the security be first exhausted). Ould v. Stoddard (1880) 54 Cal, 613; Felton v. West (1894) 102 Cal. 266, 36 Pac. 676; Commercial Bank v. Kershener (1898) 120 Cal. 495, 52 Pac. 848; Murphy v. Fellman Commercial Trust and Savings Bank (1919) 43 Cal. App. 579, 185 Pac. 485.

7 New York Code of Civil Procedure (1850) p. 385.

8 At common law on default of the mortgagor, the mortgagee could (1) sue on the note, (2) foreclose the mortgage, and (3) hring an action of ejectment. 3 JONES, MORTGAGES (1928) \$1565. However, under the common law a mortgage involved a conveyance of title to the mortgagee and foreclosure only served to cut off the equity of redemption.

In California, the actions of ejectment and strict foreclosure were made mapplicable to mortgages hy the adoption of the "lien" theory [McMillan v. Richards (1858) 9 Cal. 365; Dutton v. Warshauer (1863) 21 Cal. 609; CAL. Code CIv. Proc. \$744] and its concomitant, statutory foredosure [CAL. CODE OF Crv. PRoc. \$726]. However, before 
the legislature was to make a procedural change that would prevent this multiplicity of actions arising under the common law. ${ }^{9}$ This purpose was accomplished by the adoption of section 726 providing for recovery in but one action, whereby the mortgaged property was subject to a judicial sale (statutory foreclosure) ${ }^{10}$ and a deficiency judgment rendered for the balance remaining due on the debt. The effect of this procedure was to make the mortgage a primary fund for the satisfaction of the debt and require that the security be exhausted before recovery on the obligation. The court, however, has considered the effect of the statute as an expression of legislative purpose and policy, and as a consequence it has become a settled rule of judicial construction in 'California that where a debt is secured, the security must first be exhausted. ${ }^{11}$ This "security first" principle was applied by the court in a situation which section 726 did not cover and at a time when no other statutory mandate existed..$^{12}$ Thus, under the law as it stands today the rule requiring the security to be exhausted before suing on the note is a different rule and one which has a wider application than the "one action" rule of section 726 . A statement of the remedies available to a secured creditor under the present law will make this important distmction more apparent.. ${ }^{13}$

Creditor with ordinary security. Where a creditor owns a debt secured by an ordinary mortgage on real or personal property his only complete remedy is that given by section 726 . It prescribes but one form of action wherein the property is sold at a judicial sale and a deficiency judgment granted for the balance, if any, remaining

the adoption of the "one action" rule in 1860, a mortgagee in California had (1) an action on the note and (2) an action of foreclosure which he could maintain independently or concurrentiy. See Felton v. West, supra note 6, at 269, 36 Pac. 676, 677.

9 "Formerly the' law allowed an action upon a promissory note, and also a suit in equity to foreclose the mortgage given to secure the note." Felton v. West, ibid. p. 269; see also Bank of Italy National Trust and Savings Ass'n. v. Bentley (1933) $217 \mathrm{Cal}$. $644,654,20$ P. (2d) $940,943$.

10 "No such proceeding is known to our law as a strict foreclosure, in which a mere equity of the mortgagor is cut off because of his breach of the condition of the mortgage; but under our system the court decrees that the estate in land held by the mortgagor at the time of the execution of the mortgage, or by him subsequently acquired, be sold in satisfaction of the debt." (Italics added.) Brooks v. Tichner et al (1863) 1 Cal. Unrep. 104, 107.

11 See cases collected in 18 CaL. JurIs. $235,8522, \mathrm{n} .5$.

12 Bank of Italy National Trust and Savings Ass'n. v. Bentley, supra note 9; see Note (1932) 20 CATIF. L. REv. 318.

13 The differences between a deed of trust and a mortgage have been greatly narrowed by the court. However, many important distinctions remain between the two forms of security. Kidd, Trust Deeds and Mortgages in California (1915) 3 CarrF. L. REv. 381; Note (1924) 12 ibid. 307; Cormack \& Irsfeld, Application of the Distinction Between Mortgages and Trust Deeds in California (1938) 26 ibid. 206; Note (1938) 27 ibid. 66.

The following discussion will indicate the differences arising in the enforcement of the two types of security which are still recognized by statute. 
due on the debt. The security is exhausted before the deficiency judgment may be obtained, even though all this is done in but one action. Since the property is sold by a judicial sale under this section, the mortgagor has a statutory right of redemption. ${ }^{14}$

Creditor with security containing a power of private sale. Where a creditor owns a debt secured by a deed of trust or a mortgage with a power of sale, two remedies are available. He may exercise the option given by section 725(a) of the Code of Civil Procedure and foreclose under section 726 , thereby treating his security just as if it were an ordinary mortgage. If the option is not exercised, however, then neither the "one action" rule nor any part of section 726 is applicable, and the creditor must resort to his power of sale. Still, under this alternative remedy the security must be exhausted by the private sale before a deficiency judgment may be had on the debt under section 580 (a).$^{15}$ It is apparent that the "security first" principle must be observed, whether the creditor pursues the remedy of statutory foreclosure or the alternative remedy of a private sale with an independent suit for a deficiency judgment. In deciding which of the two remedies to follow, there are several factors to be considered by the creditor. Under the private sale there is no right of redemption involved..$^{16}$ However, in view of the enactment of section 580(a) in 1940 which precludes a deficiency judgment where there has been a private sale, it will be advantageous in most cases for the creditor who has a trust deed or mortgage with power of sale to exercise the option to foreclose given by section 725 (a), if there is a possibility the security will not adequately cover the debt. ${ }^{17}$ As to the nature of the two remedies, it appears from a recent case that "The right to enforce a deed of trust by (1) trustees sale proceedings; and (2) foreclosure of the deed of trust as a mortgage, are alternative consistent remedies. The institution of one such proceeding does not preclude subsequent enforcement by the alternative proceeding." 18

As a general rule a secured creditor enforcing his debt will prefer

14 CaL. Code or Crv. Proc. $\$ 702$ (one year).

15 This statutory requirement is a codification of the rule set forth in Bank of Italy National Trust and Savings Ass'n. v. Bentley, supra note 9.

${ }^{16}$ In the case of mortgage with a power of sale where the mortgagee hecomes the purchaser of the property under the private sale, there is considerable doubt in the law whether or not a statutory right of redemption exists. However, it is very unlikely that the issue will arise in the future and the question is, at most, an academic one. Benhain v. Rowe (1852) 2 Cal. 387; but see Kidd, op. cit. supra note 13, at 388.

${ }^{17}$ It should be noted that section 580(d) of the Code of Civil Procedure is not retroactive, and thus it apphes only to trust deeds and mortgages with a power of salc executed after 1940.

18 Carpenter v. Hamilton (June, 1943) 59 A. C. A. 157, 160, 138 P. (2d) 353, 354. See Note (1937) 107 A. L. R. 721. 
to exhaust his security first whether this be done by foreclosure or a private sale under the power given in the mortgage or deed of trust. Suppose, however, he elects to waive his security and sue on the debt alone? In other words, may a secured creditor recover a valid personal judgment on the debt without exhausting the security, and if so what rights does he retain in the security?

In view of the recent decision in Salter v. Urlich, ${ }^{19}$ a personal judgment recovered on the note is valid if section 726 or the "security first" rule is not pleaded as a defense; ${ }^{20}$ although it amounts to an election of remedies and the creditor loses all rights to his security, thereby relegating himself to the position of an ordinary judgment creditor. In reaching this result the California Supreme Court recognized three principles which have developed from the earlier decisions and represent important refinements in the rules of law governing the enforcement of a secured debt.

(1) The "security first" rule is an affirmative defense which must be set up by the debtor. ${ }^{21}$ This rule is similar in effect to the statute of limitations in that failure to plead it results in a waiver of the defense. However, the issue is not raised by a general demurrer, ${ }^{22}$ nor apparently by a special demurrer; ${ }^{23}$ but requires an affirmative allegation in the answer. ${ }^{24}$

(2) Even where the issue of security is properly raised, a judgment may be rendered on the debt alone in certain cases. Many ex-

10 (May, 1943) 22 A. C. 262, 138 P. (2d) 7. The defendant brought an action on the note without mention of the security and obtained a personal judgment by default. After execution issued, the secured property was sold to him in partial satisfaction of the default judgment. However, before delivery of the execution sale deed, the plaintiff's assignor foreclosed a lien against the property. Plaintiff then brought this quiet title action claiming the default judgment void since the defendant did not proceed under section 726 of the Code of Civil Procedure. Held: since the benefits of section 726 had been waived by the debtor, the default judgment was not void and could not be collaterally attacked by the plaintiff; and therefore title to the property was in the defendant (subject to the lien of the street improvement bond).

Under the decision in this same case by the district court of appeal, the defendant's title was not subject to the lien. Salter v. Urlich (1942) 55 A. C. A. 412, 130 P. (2d) 715. Wood, J. dissenting.

20 In Salter v. Urlich, supra note 19, the court actually held that such a judgment was not subject to collateral attack. However, since the court concedes that the requirement that the security be exhausted first is an aftirmative defense and no defense was made, the judgment would seem perfectly valid and not even subject to direct attack.

21 It is only the primary debtor who has the right to set up the affirmative defense that the note is secured. Knowles v. Sandercock (1895) 107 Cal. 629, 40 Pac. 1047; Martin v. Becker (1915) 169 Cal. 301, 146 Pac. 665.

22 Hibernia S. \& L. Soc. v. Thornton (1897) 117 Cal. 481, 49 Pac. 573 (althougl the defendant requested a judgment on the pleadings, this motion was treated by the court as a general demurrer).

23 Tucker v. Howe (1934) 139 Cal. App. 161, 33 P. (2d) 1055.

24 Crescent Lumber Co. v. Larson (1913) 166 Cal. 168, 135 Pac. 502; Hibernia S. \& L. Soc. v. Thornton, supra note 22 ; Kempton v. Superior Court (1934) 3 Cal. App. (2d) 374, 39 P. (2d) 846; see Harden v. Ware (1880) 2 Cal. Unrep. 72. 
ceptions have developed to the absolute rule laid down in Barbieri v. Ramelli ${ }^{25}$ (that no recovery could be had before exhausting the security), ${ }^{26}$ and today it seems settled that a creditor ". . . may be able to show he has a right to recover despite the fact that security was given". ${ }^{2 \tau}$

(3) Under the doctrine of election of remedies which developed from the early case of Ould $v$. Stoddard, ${ }^{28}$ the creditor by recovering on the debt alone loses all rights to the security. ${ }^{29}$ This significant doctrine is based on the one action provision of section $726^{30}$ and offers an important safeguard to the debtor. ${ }^{31}$ Even if the "security first" requirement were abolished entirely, there could be but one action for the recovery of a secured debt in California in view of the doctrine of election of remedies.

Although the foregoing principles were accepted by the court in Salter v. Urlich, ${ }^{32}$ the purported theory on which the decision rests is that a subsequent waiver of the benefits of section 726 by the debtor is valid. The decision in Winkleman $v$. Sides ${ }^{33}$ and section 2953 of the Civil Code only intend to prohibit a waiver in advance of the benefits of section 726, and not a subsequent waiver (which arose in the Urlich case from the failure of the debtor to set up the defense that the note was secured).

The soundness of the decision, it is submitted, rests on a much stronger basis than that suggested by the court. ${ }^{34}$ Underlying the

25 (1890) \&4 Cal. 154, 23 Pac. 1086.

26 Note (1937) 108 A. L. R. 397 (discussing the development of the exceptions to the absolute rule set forth in Barbieri v. Ramelli, ibid.); compare Security First Nat. Bank of Los Angeles v. Chapman (1939) 31 Cal. App. (2d) 182, 87 P. (2d) 724.

27 Salter v. Urhich, supra note 19 , at 266,138 P. (2d) at 9.

28 (1880) 54 Cal. 613.

29 While in Ould v. Stoddard the judgment on the note was obtained in another state, the same rule has been held applicable where the judgment on the note was recovered in California. Campan v. Molle (1899) 124 Cal. 415, 57 Pac. 208; see Note (1937) 25 CALIF. L. REv. at 585.

30 "The institution and maintenance of this action [to foreclose the mortgage], therefore, is expressly prohibited by the provisions of section 726 of the Code of Civil Procedure. Ould v. Stoddard (1880) 54 Cal. 613; Western Fuel Co. v. S. G. Lewald (1922) 190 Cal. 25, 210 Pac. 419." Bayless v. Ames (1929) 207 Cal. 54, 60, 276 Pac. 1011, 1013.

31 For a general discussion of the effect on the creditor's rights in the mortgage by recovery of a judgment on the note alone, see Note (1939) 121 A. L. R. 917, 926.

32 Supra note 19. 752.

33 (1939) 31 Cal. App. (2d) 387, 88 P. (2d) 147 ; noted in (1939) 27 CALIF. L. Rev.

${ }^{34}$ The opinion in Salter v. Urhich should be criticized for confusing section 726 with its corollary, the rule requiring the security to be exhausted first. Since a deed of trust was involved and there was no election to pursue the foreclosure remedy, section 726 was not applicahle to the case. Therefore, there could be no question of a waiver by the debtor of the benefits of section 726. Rather the question concerned the validity of a waiver of the rule requiring the security to be exhausted first. 
cases one finds the notion that the "security first" rule found in sections 726 and 580(a) of the Code of Civil Procedure is for the benefit of the debtor. ${ }^{35}$ This impression would be sound were it not for the existence in California of the doctrine of election of remedies, which was reiterated in the Urlich case. By suing on the debt alone, the creditor in California waives his rights to the security. ${ }^{36}$ By exhausting the security first, he retains his rights in both the security and the debt. It is apparent therefore that the "security first" requirement operates actually for the benefit of the creditor rather than the debtor. Only in an unusual case where the security is relatively small and the debtor is financially responsible would a prudent creditor sue on the debt alone. However, the debtor gains nothing by setting up the defense that the note is secured, unless it is the practical advantage of delaying recovery; except perhaps in a case where the debtor has transferred the secured property and still remains the primary debtor of the obligation. In the normal situation, then, the creditor by pursuing a less complete remedy waives some of his rights. It seems strange to say that the debtor should be permitted to set up an affirmative defense which serves to compel the creditor to enjoy a more complete remedy.

Certainly the court reached a desirable result in Salter v. Ulrich in allowing a creditor to obtain a valid personal judgment on the debt where the debtor failed to set up the defense that the note was secured. It is submitted that on careful reconsideration of the history, the logic, and the policy of the law governing the enforcement of a secured debt, a creditor should be allowed to waive his security and obtain a personal judgment on the debt as a matter of right, except where the debtor is in such a peculiar position that he will lose the benefit of the security if it is not exhausted by the creditor.

Aldo P. Guidotti.

35 "Every reason for the existence of the rule [security first] discloses and declares that it was designed for the benefit of the primary debtor, and indeed it is so decided." Martin v. Becker (1915) 169 Cal. 301, 305, 146 Pac. 665, 667; see also Bank of Italy National Trust and Savings Ass'n v. Bentley, supra note 9.

36 Salter v. Urlich, supra note 19; Bayless v. Ames, supra note 30; Campan v. Molle, supra note 29; Commercial Bank v. Kershener, supra note 6; Ould v. Stoddard, supra note 28. 